ARTICLE

DOI: $10.1038 / \mathrm{s} 41467-017-00467-\mathrm{x}$

\title{
Rechargeable aqueous zinc-manganese dioxide batteries with high energy and power densities
}

\author{
Ning Zhang (iD) ${ }^{1}$, Fangyi Cheng (1) ${ }^{1,2}$, Junxiang Liu' ${ }^{1}$, Liubin Wang ${ }^{1}$, Xinghui Long ${ }^{3}$, Xiaosong Liu ${ }^{3}$, \\ Fujun Li (iD ${ }^{1} \&$ Jun Chen ${ }^{1,2}$
}

\begin{abstract}
Although alkaline zinc-manganese dioxide batteries have dominated the primary battery applications, it is challenging to make them rechargeable. Here we report a high-performance rechargeable zinc-manganese dioxide system with an aqueous mild-acidic zinc triflate electrolyte. We demonstrate that the tunnel structured manganese dioxide polymorphs undergo a phase transition to layered zinc-buserite on first discharging, thus allowing subsequent intercalation of zinc cations in the latter structure. Based on this electrode mechanism, we formulate an aqueous zinc/manganese triflate electrolyte that enables the formation of a protective porous manganese oxide layer. The cathode exhibits a high reversible capacity of $225 \mathrm{mAh} \mathrm{g}^{-1}$ and long-term cyclability with $94 \%$ capacity retention over 2000 cycles. Remarkably, the pouch zinc-manganese dioxide battery delivers a total energy density of $75.2 \mathrm{Wh} \mathrm{kg}^{-1}$. As a result of the superior battery performance, the high safety of aqueous electrolyte, the facile cell assembly and the cost benefit of the source materials, this zinc-manganese dioxide system is believed to be promising for large-scale energy storage applications.
\end{abstract}

\footnotetext{
${ }^{1}$ Key Laboratory of Advanced Energy Materials Chemistry (Ministry of Education) and State Key Laboratory of Elemento-Organic Chemistry, College of Chemistry, Nankai University, Tianjin 300071, China. ${ }^{2}$ Collaborative Innovation Center of Chemical Science and Engineering, Nankai University, Tianjin 300071, China. ${ }^{3}$ State Key Laboratory of Functional Materials for Informatics, Shanghai Institute of Microsystem and Information Technology, Chinese Academy of Sciences, Shanghai 200050, China. Correspondence and requests for materials should be addressed to F.C. (email: fycheng@nankai.edu.cn) or to J.C. (email: chenabc@nankai.edu.cn)
} 
$\mathrm{T}$ here is ever increasing demand of advanced battery technologies with high safety and low cost for applications in portable electronics, electrified vehicles, and renewable energy storage ${ }^{1-7}$. Although lithium-ion batteries have gained great improvement in energy/power density and life span, the safety issues associated with flammable organic electrolytes and the growing concerns of the price and availability of Li resources impede their large-scale deployment. Battery chemistries based on electrochemical intercalation/storage of $\mathrm{Na}^{+}, \mathrm{K}^{+}, \mathrm{Mg}^{2+}$, and $\mathrm{Zn}^{2+}$ in aqueous electrolytes have been considered as promising alternatives, because of high safety, materials abundance, and environmental friendliness ${ }^{8-19}$. Rechargeable $\mathrm{Zn}$-ion batteries (ZIBs) are particularly attractive as zinc features higher water compatibility and stability than alkaline metals, allows multivalent charge transport carriers, and can be produced and recycled with mature industrial process ${ }^{20-25}$.

Zinc-manganese dioxide $\left(\mathrm{Zn}-\mathrm{MnO}_{2}\right)$ batteries have dominated the primary battery market because of low cost, high safety, and easy manufacturing ${ }^{26-28}$. It is highly intriguing to develop rechargeable $\mathrm{Zn}-\mathrm{MnO}_{2}$ batteries. Nevertheless, previous attempts are plagued by poor cycling performance due to the formation of irreversible discharged species (e.g., $\mathrm{Mn}(\mathrm{OH})_{2}$ and $\mathrm{ZnO}$ at cathode and anode, respectively) in alkaline electrolytes ${ }^{29-31}$. Although alkaline $\mathrm{Zn}-\mathrm{MnO}_{2}$ batteries (Fig. 1a) were shown rechargeable for extended cycles, the delivered capacity is limited at shallow depth of discharge $(\sim 10 \%)^{32}$. Recently, the rechargeability of aqueous $\mathrm{Zn}-\mathrm{MnO}_{2}$ batteries has been improved by using mild acidic electrolyte (e.g., aqueous $\mathrm{ZnSO}_{4}$ solution) ${ }^{33-37}$. However, the reaction mechanism of $\mathrm{MnO}_{2}$ polymorphs remains elusive and controversial. For example, electrochemical $\mathrm{Zn}$-insertion in $\alpha-\mathrm{MnO}_{2}$ is shown to undergo phase transition from tunneled structure to spinel $\mathrm{ZnMn}_{2} \mathrm{O}_{4}{ }^{33}$, layered Zn-buserite ${ }^{36}$, or birnessite ${ }^{38}$, most of which collapse upon cycling. A different mechanism was referred to the conversion reaction between $\alpha-\mathrm{MnO}_{2}$ and $\mathrm{MnOOH}^{35}$. For $\gamma-\mathrm{MnO}_{2}$, complex mutiple-phase transformation was proposed on discharge, involving spinel-type $\mathrm{ZnMn}_{2} \mathrm{O}_{4}$, tunnel-type $\gamma-\mathrm{Zn}_{x} \mathrm{MnO}_{2}$, and layered-type $\mathrm{L}^{-} \mathrm{Zn}_{x} \mathrm{MnO}_{2}{ }^{34}$. Additionally, the $\mathrm{Zn}$-insertion properties in aqueous $\mathrm{ZnSO}_{4}$ electrolyte are found to vary among polymorphs: $\alpha-\mathrm{MnO}_{2}$ featuring $(2 \times 2)+(1 \times 1)$ tunnel structure $^{39}$ and $\gamma-\mathrm{MnO}_{2}$ with $(1 \times 2)+(1 \times 1)$ tunnels exhibit high capacity $\left(150-300 \mathrm{mAh} \mathrm{g}^{-1}\right)^{34,36}$, whereas the most stable $(1 \times 1)$ tunneled $\beta-\mathrm{MnO}_{2}$ phase ${ }^{40,} 41$ hardly incorporates $\mathrm{Zn}^{2+}$ ions $^{33}$ due to narrow tunnels ${ }^{42}$. Furthermore, in the widely investigated $\quad \mathrm{ZnSO}_{4}$ electrolyte, $\mathrm{MnO}_{2}$ generally suffers from capacity loss due to the dissolution of $\mathrm{Mn}^{2+}$ from $\mathrm{Mn}^{3+}$ disproportionation ${ }^{34,35}$. Pre-addition of $\mathrm{Mn}^{2+}$ salt is proposed to improve capacity retention ${ }^{35}$ but the underneath mechanism remains unclear. Our previous study indicates that the use of zinc salt with bulky anion (e.g., $\mathrm{CF}_{3} \mathrm{SO}_{3}^{-}$) benefits reactivity and stability of $\mathrm{Zn}$ anode and spinel $\mathrm{ZnMn}_{2} \mathrm{O}_{4}$ cathode ${ }^{24}$. Therefore, elucidating the electrode reactions of $\mathrm{MnO}_{2}$ and exploiting compatible electrolyte are desirable in developing rechargeable aqueous $\mathrm{Zn}-\mathrm{MnO}_{2}$ batteries.

Herein, we report high-performance rechargeable aqueous $\mathrm{Zn}-\mathrm{MnO}_{2}$ cells based on $\mathrm{MnO}_{2}$ cathode, $\mathrm{Zn}$ anode, and $\mathrm{Zn}\left(\mathrm{CF}_{3} \mathrm{SO}_{3}\right)_{2}$ electrolyte with $\mathrm{Mn}\left(\mathrm{CF}_{3} \mathrm{SO}_{3}\right)_{2}$ additive. For the widely investigated $\alpha-, \beta$-, and $\gamma-\mathrm{MnO}_{2}$ polymorphs, we elucidate a common electrode reaction mechanism, by combining electrochemical measurements, X-ray diffraction analysis (XRD), elemental analysis, transmission electron microscopy (TEM), and synchrotron X-ray absorption spectroscopy (XAS). Interestingly, in the exemplified $\beta-\mathrm{MnO}_{2}$ that has been previously demonstrated unfavorable for $\mathrm{Zn}$ intercalation, a layer-type phase (i.e., $\mathrm{Zn}$-buserite $\mathrm{B}-\mathrm{Zn}_{x} \mathrm{MnO}_{2} \cdot n \mathrm{H}_{2} \mathrm{O}$ ) is generated during the initial discharge, followed by reversible insertion/extraction of $\mathrm{Zn}^{2+}$ ions in the layered structure (Fig. $1 \mathrm{~b}$ ). Up to $\sim 0.5 \mathrm{Zn}$ per molecular $\mathrm{MnO}_{2}$ is accommodated on discharging, along with disproportionated $\mathrm{Mn}$ dissolution and capacity fade. We significantly improve the cycling stability of $\mathrm{Zn}-\mathrm{MnO}_{2}$ cell by employing concentrated $\mathrm{Zn}\left(\mathrm{CF}_{3} \mathrm{SO}_{3}\right)_{2}$ electrolyte and $\mathrm{Mn}$ $\left(\mathrm{CF}_{3} \mathrm{SO}_{3}\right)_{2}$ additive (Fig. 1c). The pre-added $\mathrm{Mn}\left(\mathrm{CF}_{3} \mathrm{SO}_{3}\right)_{2}$ is found to suppress $\mathrm{Mn}^{2+}$ dissolution and result in the formation of a uniform porous $\mathrm{MnO}_{x}$ nanosheet layer on the cathode surface, which helps to maintain the electrode integrity. Remarkably, $\beta-\mathrm{MnO}_{2}$ exhibits high reversible capacity, high rate capability, and stable cyclability. We further demonstate a soft-packed $\mathrm{Zn}-\mathrm{MnO}_{2}$ full cell that delivers a reversible capacity of $1550 \mathrm{mAh}$ with a total energy density of $75.2 \mathrm{Wh} \mathrm{kg}^{-1}$ after 50 cycles.

\section{Results}

Materials synthesis and characterization. We selected pyrolusite $\beta-\mathrm{MnO}_{2}$ as a model polymorph, which has been previously demonstrated to exhibit extremely poor electrochemical activity ${ }^{33}$ and was prepared by a simple hydrothermal route in this study (detailedly described in experimental section). X-ray diffraction patterns (XRD, Supplementary Fig. 1a) reveals high purity of the
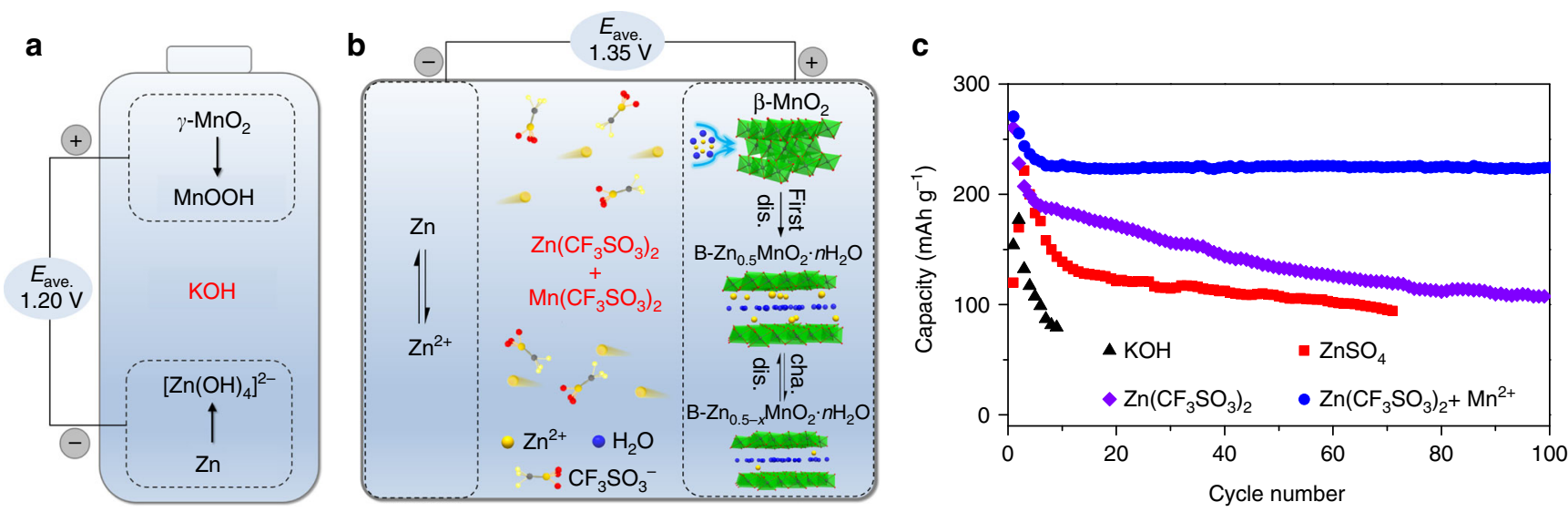

Fig. $1 \mathrm{Zn}-\mathrm{MnO}_{2}$ battery chemistry. Schematic illustration of a the primary alkaline $\mathrm{Zn}-\mathrm{MnO}_{2}$ battery using $\mathrm{KOH}$ electrolyte and $\mathbf{b}$ the rechargeable $\mathrm{Zn}-\mathrm{MnO}_{2}$ cell using $\mathrm{CF}_{3} \mathrm{SO}_{3}{ }^{-}$-based electrolyte. c Comparison of the cycling performance of $\mathrm{Zn}-\mathrm{MnO}_{2}$ cells with electrolytes of $45 \mathrm{wt} . \% \mathrm{KOH}$ (at $0.32 \mathrm{C}$ ), $3 \mathrm{M} \mathrm{ZnSO}_{4}, 3 \mathrm{M} \mathrm{Zn}\left(\mathrm{CF}_{3} \mathrm{SO}_{3}\right)_{2}$, and $3 \mathrm{M} \mathrm{Zn}\left(\mathrm{CF}_{3} \mathrm{SO}_{3}\right)_{2}$ with $0.1 \mathrm{M} \mathrm{Mn}\left(\mathrm{CF}_{3} \mathrm{SO}_{3}\right)_{2}$ additive at $0.65 \mathrm{C}$. $n \mathrm{C}$ equals the rate to charge/discharge the thereotical capacity $\left(308 \mathrm{mAh} \mathrm{g}^{-1}\right.$ ) of $\mathrm{MnO}_{2}$ in $1 / n$ hours 

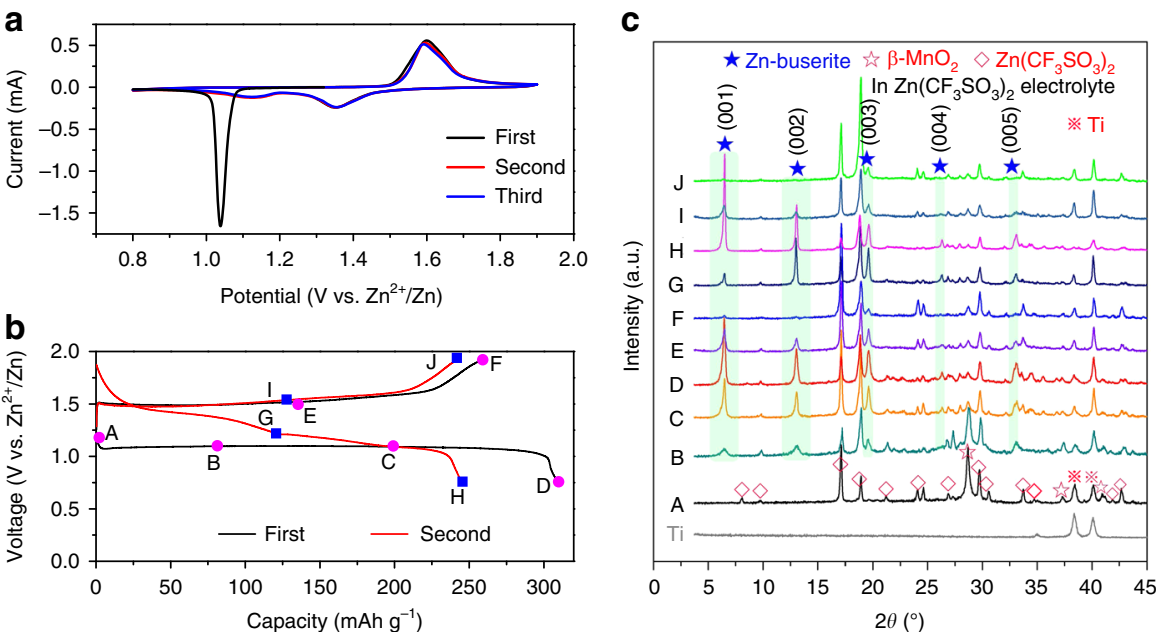

Fig. 2 Electrochemical and structural evolution of $\beta-\mathrm{MnO}_{2}$ in $\mathrm{Zn}-\mathrm{MnO}_{2}$ cell. a Cyclic voltammograms of $\beta-\mathrm{MnO}_{2}$ electrode at a scan rate of $0.1 \mathrm{mV} \mathrm{s}{ }^{-1}$ from 0.8 to $1.9 \mathrm{~V}$. $\mathbf{b}$ Typical charge/discharge curves for the initial two cycles at $0.32 \mathrm{C}$ in $3 \mathrm{M} \mathrm{Zn}\left(\mathrm{CF}_{3} \mathrm{SO}_{3}\right)_{2}$ aqueous electrolyte. The points $\mathrm{A}-\mathrm{J}$ marked the states where data were collected for XRD analysis. c XRD patterns of $\beta-\mathrm{MnO}_{2}$ electrode at selected states during the first and second cycles

formed tetragonal phase (JCPDS no. 24-735) with $\mathrm{P} 42 / \mathrm{mnm}$ space group. Scanning electron microscope (SEM, Supplementary Fig. 1b) of the sample displays nanorod morphology with average length of $2 \mu \mathrm{m}$ and width of 100-200 nm. Polymorphs of $\alpha-\mathrm{MnO}_{2}$ and $\gamma-\mathrm{MnO}_{2}$ nanorods were also synthesized via hydrothermal technique (Supplementary Fig. 2; Supplementary Methods). Commerical $\beta-\mathrm{MnO}_{2}$ powders with large particle size of $\sim 2 \mu \mathrm{m}$ (Supplementary Fig. 3) were employed for comparison.

Electrode reaction mechanism. Figure $2 \mathrm{a}$ shows the cyclic voltammograms (CVs) of $\beta-\mathrm{MnO}_{2}$ in aqueous $3 \mathrm{M} \mathrm{Zn}\left(\mathrm{CF}_{3} \mathrm{SO}_{3}\right)_{2}$ electrolyte. A sharp peak at around $1.06 \mathrm{~V}$ is observed during the first cathodic sweeping. In the following cycles, the CV curves are well repeated with two cathodic peaks located at 1.35 and $1.17 \mathrm{~V}$ and an overlapped anodic peak at $1.6 / 1.65 \mathrm{~V}$. The significant difference in $\mathrm{CV}$ profiles between the initial and subsequent cycles suggests phase transition. Figure $2 \mathrm{~b}$ shows the typical galvanostatic profiles of $\beta-\mathrm{MnO}_{2}$ at $0.32 \mathrm{C}$. The first discharge curve displays a flat plateau at around $1.08 \mathrm{~V}$ while the second cycle presents two slopping discharge plateaus, in line with the $\mathrm{CV}$ results. Notably, the initial discharge capacity reaches $307 \mathrm{mAh} \mathrm{g}^{-1}$, which approaches the theoretical capacity of $308 \mathrm{mAh} \mathrm{g}^{-1}$ (based on $\mathrm{MnO}_{2}$ ) and corresponds to $0.5 \mathrm{Zn}^{2+}$ per $\mathrm{MnO}_{2}$. The evolution of $\mathrm{CV}$ profiles and discharge plateaus indicates different mechanism of $\mathrm{Zn}^{2+}$ intercalation in $\mathrm{MnO}_{2}$ electrode $^{36,43}$, as discussed below.

To probe the structural evolution of $\beta-\mathrm{MnO}_{2}$ in the discharge/ charge process, ex-situ XRD patterns (Fig. 2c) were recorded at the selected states (marked points in Fig. 2b). On first discharging $(\mathrm{A} \rightarrow \mathrm{D})$, the characteristic peaks of $\beta-\mathrm{MnO}_{2}$ are gradually weakened and new phase arises. Besides the peaks designated to the $\mathrm{Zn}\left(\mathrm{CF}_{3} \mathrm{SO}_{3}\right)_{2}$ salt, new peaks emerge at $6.47,13.00,19.58$, 26.28 , and $32.93^{\circ}$, which could be assigned to reflections from the (001)-(005) crystallographic planes of a layered Zn-buserite phase, respectively. The electrolyte salt is precipitated on the surface of both $\mathrm{MnO}_{2}$ cathode and $\mathrm{Zn}$ anode but can be easily removed by immersing and rinsing with water (Supplementary Fig. $4 \mathrm{a}-\mathrm{c}$ ). Notably, the XRD pattern of the rinsed cathode differs from that of previously reported species (e.g., $\mathrm{MnOOH}^{35}$, spinel $\mathrm{ZnMn}_{2} \mathrm{O}_{4}{ }^{33}$, birnessite ${ }^{38}$, tunneled $\gamma-\mathrm{ZnMnO}_{2}{ }^{34}$, and layered $\mathrm{L}-\mathrm{Zn}_{x} \mathrm{MnO}_{2}{ }^{34}$ ) in discharged $\mathrm{MnO}_{2}$ electrodes (Supplementary Fig. $4 \mathrm{~d}$ ). Rietveld refinement of the XRD data of the discharged electrode suggests the formation of $\mathrm{Zn}$-buserite phase (Supplementary Fig. 4e). The exact structural motif of $\mathrm{Zn}$-buserite is not determined yet, but will be further investigated in the future.The Zn-buserite phase, commonly found in layered $\mathrm{Mn}$ oxide mineral ${ }^{44-46}$, contains $\mathrm{H}_{2} \mathrm{O}$ layers in the channels between two $\mathrm{MnO}_{6}$ octohedron slabs (Fig. 1b), featuring a similar structure with Ca-buserite ${ }^{44}$ (JCPDS No.50-0015). $\mathrm{Zn}^{2+}$ cations reside above and below the Mn vacant sites and are coordinated with three $\mathrm{O}$ atoms adjacent to the vacancies and three $\mathrm{O}$ atoms from interlayer $\mathrm{H}_{2} \mathrm{O}^{36}, 44-46$. The presence of $\mathrm{H}_{2} \mathrm{O}$ in the discharged species was validated using thermal gravimetric analysis (TGA), indicating a composition of $\sim 2.28$ molecular $\mathrm{H}_{2} \mathrm{O}$ per formula of Zn-buserite (Supplementary Fig. 5). In the followed charging process $(D \rightarrow F)$, the intensity of characteristic peaks for the layered phase was gradually weakened upon extraction of $\mathrm{Zn}$ ions. This peak attenuation could be explained by the decrease of scattering atom concentration in unit cell and the weakening of $\mathrm{Zn}-\mathrm{O}$ interaction due to $\mathrm{Zn}$ egress. Similar intensity variation of $(00 l)$ reflection has been observed on layered intercalation electrodes such as vanadium oxides ${ }^{9,47}$. In the second cycle, the signals of layered compound were reversibly strengthened/ weakened upon $\mathrm{Zn}^{2+}$ insertion/extraction. The presence of $\beta-\mathrm{MnO}_{2}$ can be observed in the initial several cycles but is not discernable after 10 cycles (Supplementary Fig. 6). We investigated the structural evolution of $\alpha-\mathrm{MnO}_{2}$ and $\gamma-\mathrm{MnO}_{2}$ cathodes as well. Interestingly, these two polymorphs undergo phase transformation to layered $\mathrm{Zn}$-buserite upon first discharging and reversible $\mathrm{Zn}$ intercalation in the layered structure on subsequent cycling (Supplementary Figs. 7 and 8), resembling the case of $\beta-\mathrm{MnO}_{2}$. The results suggest common electrode reaction mechanism in tunneled polymorphs of $\mathrm{MnO}_{2}$, which to the best of our knowlege, is first elucidated in mild acidic electrolytes.

The structural evolution of $\beta-\mathrm{MnO}_{2}$ electrode was further investigated by ex-situ TEM analysis. Figure $3 \mathrm{a}, \mathrm{b}$ displays the TEM and high-resolution TEM (HRTEM) images at the initial state, where the lattice fringes can be indexed to the (110) plane of $\beta-\mathrm{MnO}_{2}$. The annular bright field-scanning TEM (ABF-STEM) image (Fig. 3c) clearly shows the atomic arrangement within the tunnel-like framework, as schematically viewed along the [100] direction of the lattice (Fig. 3d). After fully discharging, the one-dimensional nanorod shape is maintained, while the surface of electrode becomes rough with the formation of aggregated nanoparticles (Fig. 3e), which is ascribed to the structural 

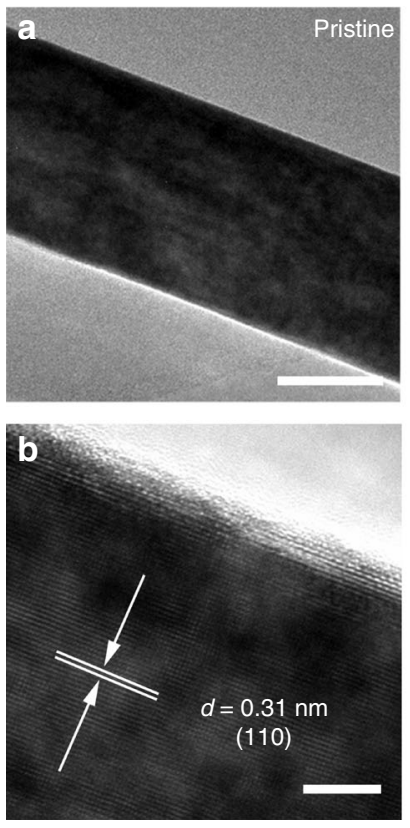
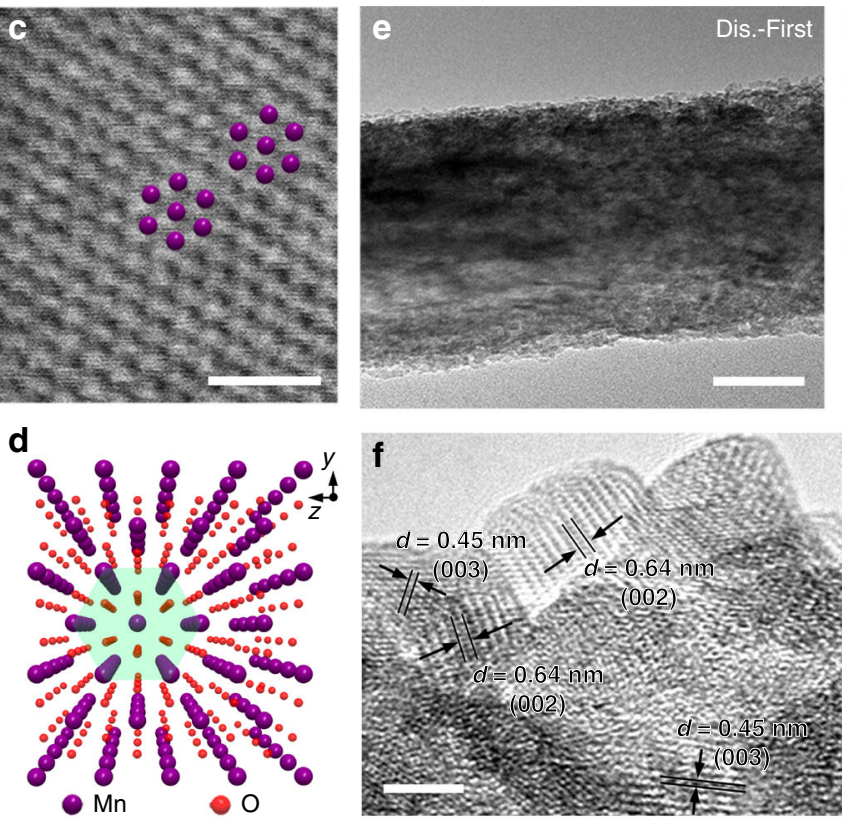
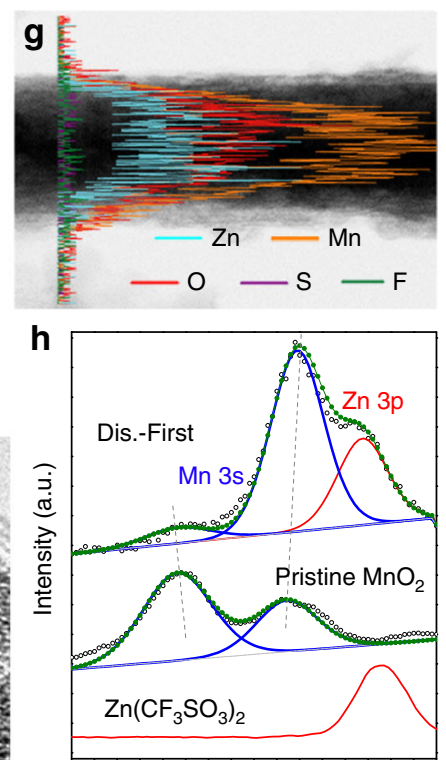

$\begin{array}{llllllll}80 & 82 & 84 & 86 & 88 & 90 & 92 & 94\end{array}$

Binding energy $(\mathrm{eV})$

Fig. 3 Microstructural and compositional analysis of $\mathrm{MnO}_{2}$. a TEM image, b HRTEM image, c ABF-STEM image, and $\mathbf{d}$ schematic atomic model (viewed from the [100] zone axis) at the initial state. e TEM image, $\mathbf{f}$ HRTEM image, $\mathbf{g}$ EDS line scanning profiles in TEM, and $\mathbf{h}$ XPS spectra of the first fully discharged electrode. Scale bars, $50 \mathrm{~nm}$ a, e; $5 \mathrm{~nm}$ b, f; and $1 \mathrm{~nm}$ c, respectively

distortion in the phase-conversion process. The observed lattice fringes with interplanar distances of $0.45,0.64$, and $1.29 \mathrm{~nm}$ correspond to the (003), (002), and (001) planes of Zn-buserite (Fig. 3f and Supplementary Fig. 9a), respectively, consistent with the $\mathrm{XRD}$ analysis.

To eliminate the impact of precipitated electrolyte salt, the discharged electrode was rinsed with water for elemental dispersive spectroscopy (EDS) and X-ray photoelectron spectroscopy (XPS) analysis. The line scanning profile in TEM (Fig. 3g) and elemental mapping (Supplementary Fig. 9b) in STEM of the discharged electrode reveal the uniform distribution of $\mathrm{Zn}, \mathrm{Mn}$ and $\mathrm{O}$, whereas $\mathrm{S}$ and $\mathrm{F}$ from electrolyte are not detectable (Fig. 3g). In XPS spectra, the energy splitting $(\Delta E)$ of Mn $3 \mathrm{~s}$ doublet peaks is 4.7 and $5.0 \mathrm{eV}$ for pristine and discharged electrodes, respectively, indicating reduced $\mathrm{Mn}$ valence after $\mathrm{Zn}$ insertion (Fig. 3h). At discharged state, a new $\mathrm{Zn} 3 \mathrm{p}$ peak appears at $92.0 \mathrm{eV}$, which is lower than that of $\mathrm{Zn}\left(\mathrm{CF}_{3} \mathrm{SO}_{3}\right)_{2}(92.7 \mathrm{eV})$ and could be assigned to the intercalated $\mathrm{Zn}$. These results confirm the presence of $\mathrm{Zn}^{2+}$ ions into the layered manganese oxide host and rule out the possibility of electrode reactions associated with $\mathrm{CF}_{3} \mathrm{SO}_{3}{ }^{-}$anions. Furthermore, the TEM images of $\beta-\mathrm{MnO}_{2}$ electrode after different cycles (Supplementary Fig. 10) indicate expansion and exfoliation of nanorods, which is attributed to the phase transition, Mn dissolution and repeated $\mathrm{Zn}^{2+}$ intercalation, and would incur capacity loss during cycling.

To gain insight into the variation of Mn oxidation state and electronic structure during the (de)intercalation process, we performed the synchrotron XAS characterization, which has been demonstrated useful to analyze manganese oxides ${ }^{48-52}$. Figure $4 \mathrm{a}$ shows the normalized Mn K-edge XANES (X-ray near edge absorption structure) profiles of $\beta-\mathrm{MnO}_{2}$ electrode at selected states in the initial two cycles. The nominal Mn valence was plotted vs. excitation energy of reference manganese oxides to establish fitted linear correlation (Fig. 4b). On discharging, the entire edge shifts toward lower energy, indicating a decrease of the average $\mathrm{Mn}$ oxidation state. The mean $\mathrm{Mn}$ valence at fully discharged state is estimated to be 3.6. During first charging, the edge position slightly shifts back to higher energy, while it remains almost unchanged in the second cycle. The interesting point is that the $\mathrm{Mn}$ valence should increase/decrease with $\mathrm{Zn}^{2+}$ intercalation/deintercalation and would approach 3 for the fully discharged electrode, as anticipated from the discharged capacity (Fig. 2b). We postulate that such unexpected observation could be ascribed to the disproportional dissolution of trivalent $\mathrm{Mn}$ species $\left(\mathrm{Mn}^{3+}{ }_{\mathrm{s}} \rightarrow \mathrm{Mn}^{4+}{ }_{\mathrm{s}}+\mathrm{Mn}^{2+}{ }_{\mathrm{aq}}\right)^{38,53}$. Analysis of Mn by inductively coupled plasma atomic emission spectrometer (ICP-AES) evidences the change of $\mathrm{Mn}$ concentration in the electrolyte (Supplementary Fig. 11; Supplementary Note 1). On discharging, the amount of dissolved $\mathrm{Mn}$ increases and corresponds to $~ 8.9 \%$ of the total manganese at full discharge. The partial dissolution of $\mathrm{Mn}$ in electrolyte is a feasible attribution to the noticeable capacity loss on cycling.

Figure $4 \mathrm{c}$ shows the EXAFS (extended X-ray absorption fine structure) spectra of $\beta-\mathrm{MnO}_{2}$ electrode at selected $\mathrm{Zn}$ (de) intercalation stages. The strongest peak located at $1.5 \AA$ is attributed to the closest oxygen (Mn-O) in the $\mathrm{MnO}_{6}$ octahedra. The peaks at 2.5 and $3.0 \AA$ are assigned to $\mathrm{Mn}$ in the edge-sharing $\left(\mathrm{Mn}-\mathrm{Mn}_{\text {edge }}\right)$ and corner-sharing ( $\left.\mathrm{Mn}-\mathrm{Mn}_{\text {corner }}\right) \mathrm{MnO}_{6}$ octahedra (Fig. 4d), respectively $y^{51,54}$. When the elcctrode was fully discharged, the relative intensity of the $\mathrm{Mn}-\mathrm{Mn}_{\text {corner }}$ peak decreased to a much larger extent than that of $\mathrm{Mn}-\mathrm{O}$ and $\mathrm{Mn}-\mathrm{Mn}_{\text {edge }}$ signals (Supplementary Fig. 12). This result is indicative of the breakage of the corner-shared $\mathrm{MnO}_{6}$ octahedra. Furthermore, the $3.0 \AA$ A peak broadens and slightly shifts to larger distance, which is related to the formation of Mn-O-Zn energy-absorbing path between the layered $\mathrm{MnO}_{6}$ octohedron slabs and inserted $\mathrm{Zn}$ ions. A comparison of the crystallographic structure between $\beta-\mathrm{MnO}_{2}$ and $\mathrm{Zn}$-buserite suggests that the co-insertion of $\mathrm{Zn}^{2+}$ and $\mathrm{H}_{2} \mathrm{O}$ and the dissolution of $\mathrm{Mn}$ distort the pyrolusite framework, leaving $\mathrm{Mn}$ vacancies in the upper/underlying layers and generating layered $\mathrm{Zn}$-buserite. This tunnel-to-layer phase transition is irreversible, as indicated by the absence of EXAFS spectra recovery on first recharge. Meanwhile, the broadened $3.0 \AA$ peak is not fully recovered after second charging, which can be attritubed to the capacity loss (Fig. 2b). Notably, XAS analysis of $\alpha-\mathrm{MnO}_{2}$ and $\gamma-\mathrm{MnO}_{2}$ electrodes (Supplementary Fig. 13) reveals similar behavior with that of $\beta$ $\mathrm{MnO}_{2}$, again suggesting common electrode reaction mechanism among different tunneled $\mathrm{MnO}_{2}$ polymorphs. 

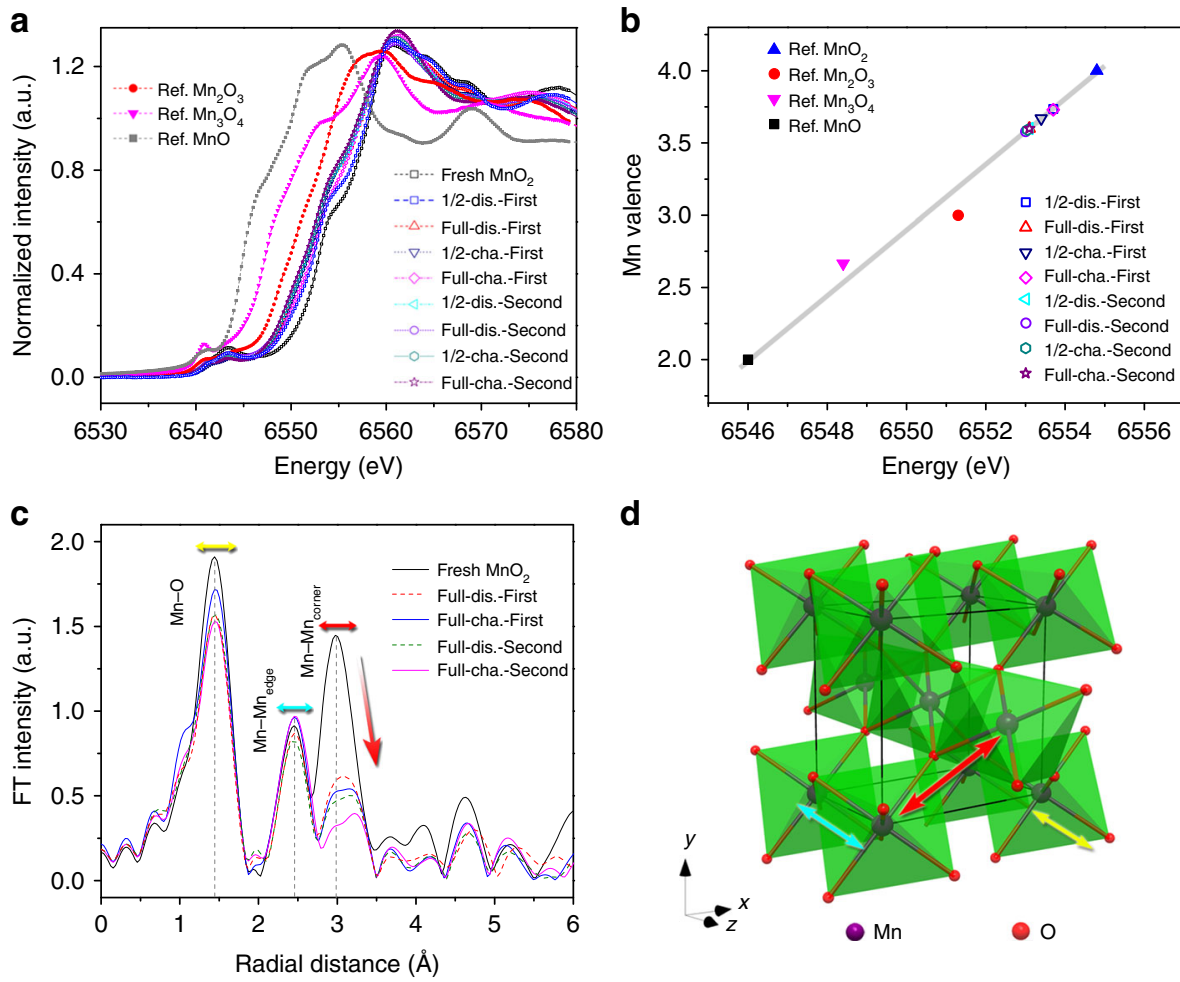

d

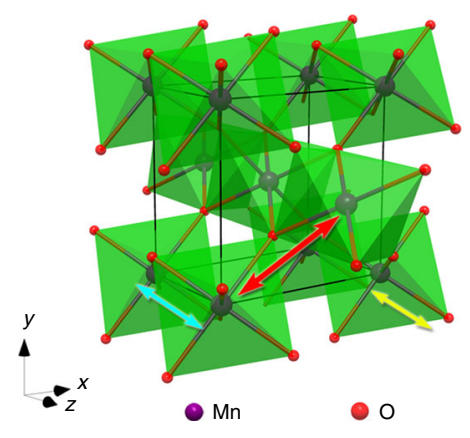

Fig. 4 XAS characterization of $\beta-\mathrm{MnO}_{2}$ electrode. a Mn-K edge XANES curves at selected discharge/charge states, with reference to standard $\mathrm{MnO}$, $\mathrm{Mn}_{2} \mathrm{O}_{3}$, and $\mathrm{Mn}_{3} \mathrm{O}_{4}$. b Fitted linear relationship between the photon energy and oxidation state of $\mathrm{Mn}$ element. c The EXAFS spectra. $\mathbf{d}$ Schematic depiction of the unit cell of $\beta-\mathrm{MnO}_{2}$
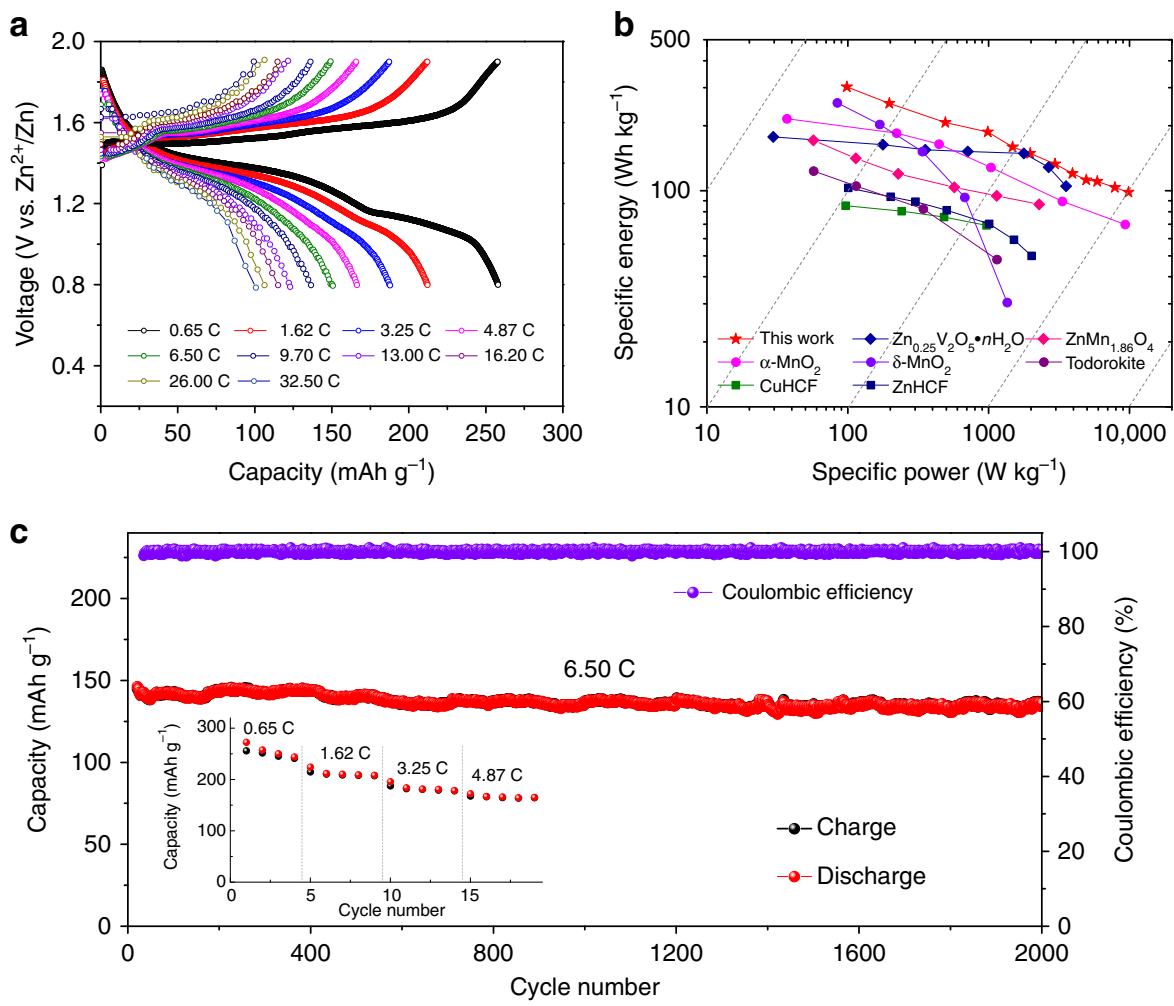

Fig. 5 Electrochemical performance of $\mathrm{Zn}-\mathrm{MnO}_{2}$ cells in $3 \mathrm{M} \mathrm{Zn}\left(\mathrm{CF}_{3} \mathrm{SO}_{3}\right)_{2}$ electrolyte with $0.1 \mathrm{M} \mathrm{Mn}\left(\mathrm{CF}_{3} \mathrm{SO}_{3}\right)_{2}$ additive. a Discharge/charge profiles at varying $\mathrm{C}$ rates. $\mathbf{b}$ The Ragone plots of $\mathrm{Zn}-\mathrm{MnO}_{2}$ battery and $\mathrm{ZIBs}$ with other reported cathode materials. Values are based on the total active mass of both cathode and anode. c Long-cycle performance at rate of $6.5 \mathrm{C}$. Inset shows the capacity evolution at the initial 19 cycles 

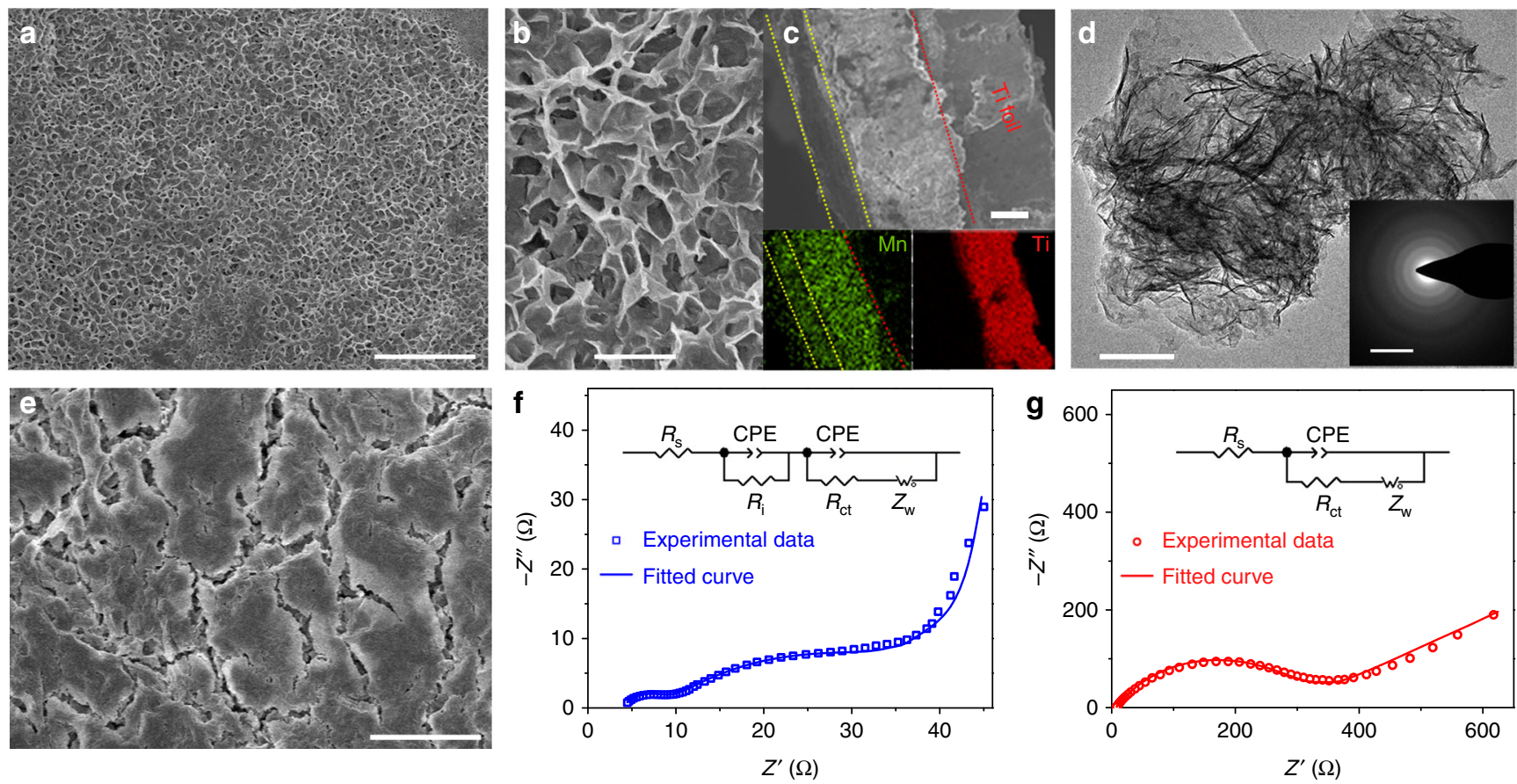

Fig. 6 Function of pre-added $\mathrm{Mn}^{2+}$ in electrolyte. $\mathbf{a}, \mathbf{b}, \mathbf{c}, \mathbf{e}$ SEM, $\mathbf{d}$ TEM images, and $\mathbf{f}, \mathbf{g}$ three-electrode-cell EIS analysis of re-obtained cathodes after ten cycles in $3 \mathrm{M} \mathrm{Zn}\left(\mathrm{CF}_{3} \mathrm{SO}_{3}\right)_{2}$ electrolyte $\mathbf{a}-\mathbf{d}$, $\mathbf{f}$ with and $\mathbf{e}, \mathbf{g}$ without $0.1 \mathrm{M} \mathrm{Mn}\left(\mathrm{CF}_{3} \mathrm{SO}_{3}\right)_{2}$ additive. Insets of $\mathbf{c}$, $\mathbf{d}$ show elemental mapping and SAED pattern, respectively. Insets of $\mathbf{f}, \mathbf{g}$ show the equivalent circuit to fit the EIS data, where $R_{\mathrm{s}}, R_{\mathrm{i}}, R_{\mathrm{ct}}, \mathrm{CPE}$, and $Z_{\mathrm{w}}$ represent series resistance, interface resistance between electrolyte and deposited layer, charge-transfer resistance, constant-phase element, and Warburg diffusion process, respectively. Scale bars, $5 \mu \mathrm{m}$ a, e; $1 \mu \mathrm{m} \mathrm{b}$; $10 \mu \mathrm{m} \mathrm{c}$; $100 \mathrm{~nm} \mathbf{d}$; and $51 / \mathrm{nm}$ (inset of $\mathbf{d}$ ), respectively

Electrochemical performance. To evaluate the electrochemical performance, coin-type $\mathrm{Zn}-\mathrm{MnO}_{2}$ cell was assembled in ambient air by using $\beta-\mathrm{MnO}_{2}$ nanorod cathode, $\mathrm{Zn}$ foil anode, filter paper separator, and aqueous $\mathrm{Zn}\left(\mathrm{CF}_{3} \mathrm{SO}_{3}\right)_{2}$ electrolyte. The concentrated $3 \mathrm{M} \mathrm{Zn}\left(\mathrm{CF}_{3} \mathrm{SO}_{3}\right)_{2}$ results in better cyclic stability than diluted electrolyte (e.g., $1 \mathrm{M}$ ) (Supplementary Fig. 14), which is ascribed to the decrease of water activity and water-induced side reactions ${ }^{4,24,55}$. As shown in Fig. 1c, the cells based on mild acidic electrolye $\left(3 \mathrm{M} \mathrm{ZnSO}_{4}, \mathrm{pH} \sim 3.4 ; 3 \mathrm{M} \mathrm{Zn}\left(\mathrm{CF}_{3} \mathrm{SO}_{3}\right)_{2}\right.$, $\mathrm{pH} \sim 3.6)$ show much better cycling performance as compared with that employing $\mathrm{KOH}$ electolyte. Meanwhile, the cell using $\mathrm{Zn}\left(\mathrm{CF}_{3} \mathrm{SO}_{3}\right)_{2}$ electrolyte delivers much higher initial discharge capacity than that of $\mathrm{ZnSO}_{4}\left(275\right.$ vs. $\left.120 \mathrm{mAh} \mathrm{g}^{-1}\right)$ at $0.65 \mathrm{C}$. However, similar capacity deterioration is observed upon cycling, due to the loss of active mass. To address this issue, we pre-added $\mathrm{Mn}^{2+}$ salts into the electrolyte to accommodate the dissolution equilibrium of $\mathrm{Mn}^{2+}$ from $\mathrm{MnO}_{2}$ electrode. By eliminating the anion effect, we selected $\mathrm{Mn}\left(\mathrm{CF}_{3} \mathrm{SO}_{3}\right)_{2}$ as the electrolyte additive, with concentration from diluted $0.01 \mathrm{M}$ to the saturated 0.1 M. The optimized electrolyte composition was found to be 3 $\mathrm{M} \mathrm{Zn}\left(\mathrm{CF}_{3} \mathrm{SO}_{3}\right)_{2}+0.1 \mathrm{M} \mathrm{Mn}\left(\mathrm{CF}_{3} \mathrm{SO}_{3}\right)_{2}$, which results in the highest Coulombic efficiency and ionic conductivity as well as high capacity of $225 \mathrm{mAh} \mathrm{g}^{-1}$ after 100 cycles (Supplementary Figs. 15 and 16).

Figure $5 \mathrm{a}$ shows the charge/discharge profiles of $\mathrm{Zn}-\mathrm{MnO}_{2}$ cells at different current densities. Discharge capacities of $258,213,188,151$, and $115 \mathrm{mAh} \mathrm{g}^{-1}$ were recorded at rates of $0.65,1.62,3.25,6.50$, and $16.20 \mathrm{C}$, respectively. Even at a high rate of $32.50 \mathrm{C}$, a reversible capacity of $100 \mathrm{mAh} \mathrm{g}^{-1}$ could be obtained. In addition, when the rate shifted back to $0.65 \mathrm{C}$, the capacity recovered to $246 \mathrm{mAh} \mathrm{g}^{-1}$, showing a strong tolerance to the rapid $\mathrm{Zn}^{2+}$ ions insertion/extraction (Supplementary Fig. 17). The superior rate performance can be further viewed from the Ragone plots (specific energy vs. specific power) by comparing the $\mathrm{Zn}-\mathrm{MnO}_{2}$ system to reported $\alpha-\mathrm{MnO}_{2}{ }^{33}, \delta-\mathrm{MnO}_{2}{ }^{56}$,
$\mathrm{Zn}_{0.25} \mathrm{~V}_{2} \mathrm{O}_{5} \cdot \mathrm{nH}_{2} \mathrm{O}^{9}, \mathrm{Zn}_{1.86} \mathrm{Mn}_{2} \mathrm{O}_{4}{ }^{24}$, todorokite ${ }^{37}, \mathrm{KCuFe}(\mathrm{CN})_{6}$ $(\mathrm{CuHCF})^{21}$, and $\mathrm{Zn}_{3}\left[\mathrm{Fe}(\mathrm{CN})_{6}\right]_{2}(\mathrm{ZnHCF})^{57}$ cathodes for aqueous ZIBs (Fig. 5b). High-specific energy and specific power $\left(254 \mathrm{Wh} \mathrm{kg}^{-1}\right.$ at $197 \mathrm{~W} \mathrm{~kg}^{-1} ; 110 \mathrm{Wh} \mathrm{kg}^{-1}$ at $5910 \mathrm{~W} \mathrm{~kg}^{-1}$ ) can be simultaneously achieved, which is promising for energy storage applications. The $\mathrm{Zn}-\mathrm{MnO}_{2}$ cell was galvanostatically discharged/charged at $6.50 \mathrm{C}$ (Fig. $5 \mathrm{c}$ ) to evaluate the long-term cycling stability. Remarkably, the reversible capacity sustains $135 \mathrm{mAh} \mathrm{g}^{-1}$ with a capacity retention of $94 \%$ over 2000 cycles and Coulombic efficiency approaching 100\%.

We also investigated the $\mathrm{Zn}-\mathrm{MnO}_{2}$ cells with $3 \mathrm{M} \mathrm{ZnSO}_{4}+0.1 \mathrm{M}$ $\mathrm{MnSO}_{4}$ and $3 \mathrm{M} \mathrm{Zn}\left(\mathrm{CF}_{3} \mathrm{SO}_{3}\right)_{2}+0.1 \mathrm{M} \mathrm{MnSO}_{4}$ electrolytes, which delivered initial discharge capacity of 110 and $205 \mathrm{mAh} \mathrm{g}^{-1}$, respectively (Supplementary Fig. 18). In $\mathrm{SO}_{4}{ }^{2-}$-based electrolyte, an increase of capacity was observed within the first several cycles, which was attributed to the activation process that has been similarly found in reported $\alpha-/ \gamma-\mathrm{MnO}_{2}$ cathodes ${ }^{34-36}$. Interestingly, the $\mathrm{CF}_{3} \mathrm{SO}_{3}{ }^{-}$-based electrolyte endows much higher initial discharge capacity $\left(275 \mathrm{mAh} \mathrm{g}^{-1}\right.$ at $\left.0.65 \mathrm{C}\right)$ and results in capacity stabilization after $\sim 10$ cycles. The different behaviors could be ascribed to the $\mathrm{Zn}\left(\mathrm{CF}_{3} \mathrm{SO}_{3}\right)_{2}$ solution that not only features higher ionic conductivity (Supplementary Fig. 19) but also enables faster kinetics and higher stability of $\mathrm{Zn}$ plating/stripping as compared with sulfate and alkaline electrolytes (Supplementary Fig. 20; Supplementary Note 2). Besides, the bulky $\mathrm{CF}_{3} \mathrm{SO}_{3}{ }^{-}$anion (vs. $\mathrm{SO}_{4}{ }^{2-}$ with double charge) could decrease the number of water molecules surrounding $\mathrm{Zn}^{2+}$ cations and reduce the solvation effect ${ }^{24}$, thus facilitating $\mathrm{Zn}^{2+}$ ions transportation and charge transfer.

Although the pre-addition of $\mathrm{Mn}^{2+}$ in electrolyte has been demonstrated to enhance the cyclability of $\mathrm{MnO}_{2}$ electrode ${ }^{35}$, the underneath mechanism remains unclear. To further understand the functions of pre-added $\mathrm{Mn}^{2+}$, we have carried out a series of analytical studies, including electrochemical measurements, XRD, Raman, XPS, XANES, and SEM/TEM. In acidic electrolyte, manganese oxides $\left(\mathrm{MnO}_{x}\right)$ such as $\mathrm{MnO}_{2}$ or $\mathrm{Mn}_{2} \mathrm{O}_{3}$ can be 
a

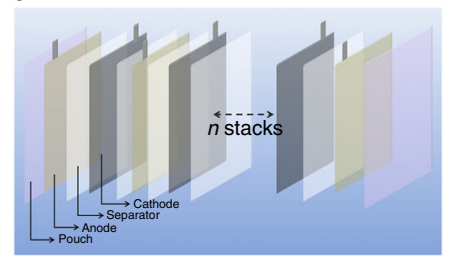

b

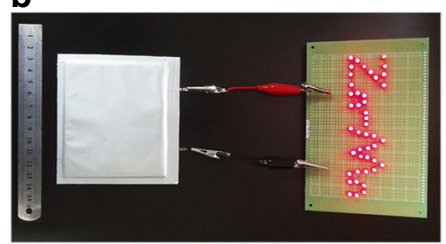

C

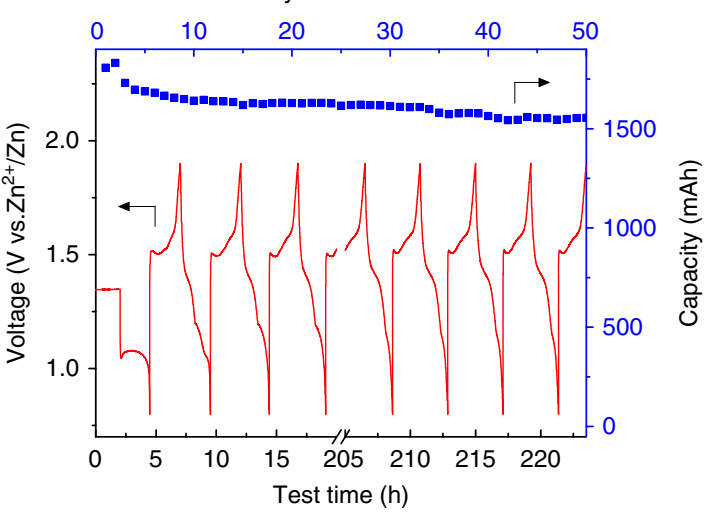

Fig. 7 Electrochemical performance of pouch-type $\mathrm{Zn}-\mathrm{MnO}_{2}$ battery. a Schematic illustration of the cell configuration with anode-separator-cathode stacks. b A digital photo of the soft-package battery powering a series of LED lights. c Cycling performance in the voltage range of 0.8-1.9 V at constant current of $0.72 \mathrm{~A}$

generated from electrolysis of $\mathrm{Mn}^{2+}$-containing solution ${ }^{32}$ based on the following reactions:

$$
\begin{array}{r}
\mathrm{MnO}_{2}+4 \mathrm{H}^{+}+2 e^{-}=\mathrm{Mn}^{2+}+2 \mathrm{H}_{2} \mathrm{O} \\
E^{\theta}=2.01 \mathrm{~V}\left(\text { vs. } \mathrm{Zn}^{2+} / \mathrm{Zn}\right) \\
\mathrm{Mn}_{2} \mathrm{O}_{3}+6 \mathrm{H}^{+}+2 \mathrm{e}^{-}=2 \mathrm{Mn}^{2+}+3 \mathrm{H}_{2} \mathrm{O} \\
E^{\theta}=2.26 \mathrm{~V}\left(\text { vs. } \mathrm{Zn}^{2+} / \mathrm{Zn}\right)
\end{array}
$$

According to Nernst equation, the required theoretical potentials to form $\mathrm{MnO}_{2}$ and $\mathrm{Mn}_{2} \mathrm{O}_{3}$ in $\mathrm{Mn}\left(\mathrm{CF}_{3} \mathrm{SO}_{3}\right)_{2}(0.1 \mathrm{M}$, pH 6.0) solution are 1.35 and $1.26 \mathrm{~V}$ (vs. $\mathrm{Zn}^{2+} / \mathrm{Zn}$ ), respectively; the corresponding values are 1.60 and $1.64 \mathrm{~V}$ in $3 \mathrm{M} \mathrm{Zn}\left(\mathrm{CF}_{3} \mathrm{SO}_{3}\right)_{2}$ electrolyte containing $0.1 \mathrm{M} \mathrm{Mn}^{2+}(\mathrm{pH} 3.8)$. This estimation is consistent with the voltammetry results of three-electrode measurements (Supplementary Fig. 21; Supplementary Note 3), which also reveals that $\mathrm{Mn}^{2+}$ is not reduced within the investigated potential windows. After charging in $3 \mathrm{M} \mathrm{Zn}$ $\left(\mathrm{CF}_{3} \mathrm{SO}_{3}\right)_{2}+0.1 \mathrm{M} \mathrm{Mn}\left(\mathrm{CF}_{3} \mathrm{SO}_{3}\right)_{2}$ electrolyte, brown deposit layer was observed on the electrode. The layer is composed of manganese oxide with $\mathrm{Mn}$ oxidation state between +3 and +4 , and features nanosheet morphology and poor crystallinity, as analyzed by SEM, XRD, Raman, XPS, and XAENS (Supplementary Fig. 22).

In post-mortem analysis of $\mathrm{Zn}-\mathrm{MnO}_{2}$ cell using $3 \mathrm{M} \mathrm{Zn}$ $\left(\mathrm{CF}_{3} \mathrm{SO}_{3}\right)_{2}+0.1 \mathrm{M} \mathrm{Mn}\left(\mathrm{CF}_{3} \mathrm{SO}_{3}\right)_{2}$ electrolyte, we also observed an interconnected porous $\mathrm{MnO}_{x}$ layer on the cathode surface after charging (Fig. 6a, b). The cross-sectional SEM image and elemental mapping images (Fig. 6c) evidence the presence of a uniform layer with thickness around $10 \mu \mathrm{m}$. TEM imaging and selected area electron diffraction (SAED) analysis reveal porous nanosheet microstructure and amorphous character of the deposited layer (Fig. 6d), which would facilitate mass diffusion. In contrast, the integrity of $\beta-\mathrm{MnO}_{2}$ electrode was seriously destroyed with the formation of cracks in $3 \mathrm{M} \mathrm{Zn}\left(\mathrm{CF}_{3} \mathrm{SO}_{3}\right)_{2}$ electrolyte without $\mathrm{Mn}\left(\mathrm{CF}_{3} \mathrm{SO}_{3}\right)_{2}$ additive (Fig. 6e). The electrode pulverization would break the electronic conducting network and increase electrode polarization, further aggravating the capacity decay. Electrochemical impedance spectroscopy (EIS) was performed in a three-electrode cell, using the dismantled cathode after ten cycles as the working electrode, platinum plate as the counter electrode, and saturated calomel electrode (SCE) as the reference electrode. The cycled electrode in $\mathrm{Mn}^{2+}$-added electrolyte displays two depressed semicircles in high frequency area and one line in low frequency region (Fig. 6f). Fitting the EIS data
(Supplementary Table 1 ) gives a series resistance $\left(R_{\mathrm{s}}, 4.5 \Omega\right)$, an interface resistance $\left(R_{\mathrm{i}}, 6.0 \Omega\right)$ between electrolyte and deposited layer, a charge-transfer resistance $\left(R_{\mathrm{ct}}, 25 \Omega\right)$ and a Warburg diffusion impedance $\left(Z_{\mathrm{w}}, 124.7 \Omega\right)$. In comparison, the cell without electrolyte additive shows higher $R_{\mathrm{s}}(8.0 \Omega), R_{\mathrm{ct}}(350 \Omega)$, and $Z_{\mathrm{w}}(1200 \Omega)$, in the absence of the apparent interface component (Fig. 6g).

Based on the above results, we propose three merits of the $\mathrm{Mn}^{2+}$ electrolyte additive for the $\mathrm{Zn}-\mathrm{MnO}_{2}$ battery: (1) accommodating and compensating $\mathrm{Mn}^{2+}$ dissolution from the electrode, (2) improving initial Coulombic efficiency and ionic conductivity of the electrolyte and (3) generating a uniform porous nanostructured $\mathrm{MnO}_{x}$ film on the cathode surface, which helps to maintain the electrode integrity and favor charge transfer. Note that the generated $\mathrm{MnO}_{x}$ layer itself contributes to nearly $2.4 \%$ of the capacity delivered by the active material (Supplementary Fig. 23). The $\mathrm{Zn}\left(\mathrm{CF}_{3} \mathrm{SO}_{3}\right)_{2}+\mathrm{Mn}\left(\mathrm{CF}_{3} \mathrm{SO}_{3}\right)_{2}$ electrolyte is also applicable to improve the cycling stability of nanostructured $\alpha-\mathrm{MnO}_{2}$ and $\gamma-\mathrm{MnO}_{2}$ cathodes (Supplementary Fig. 24a, b). Furthermore, commercial $\beta-\mathrm{MnO}_{2}$ powders with irregular shape and micrometer particle size (Supplementary Fig. 3) also exhibit considerable capacity (132 $\mathrm{mAh} \mathrm{g}^{-1}$ at $\left.0.65 \mathrm{C}\right)$ and cyclability (200 cycles) in this electrolyte (Supplementary Fig. 24c, d).

The $\mathrm{Zn}$ anode was also investigated to understand the high-performing $\mathrm{Zn}-\mathrm{MnO}_{2}$ cell chemistry (Supplementary Figs. 25-28). Post-mortem analysis of cycled $\mathrm{Zn}$ in threeelectrode cell with $3 \mathrm{M} \mathrm{Zn}\left(\mathrm{CF}_{3} \mathrm{SO}_{3}\right)_{2}+0.1 \mathrm{M} \mathrm{Mn}\left(\mathrm{CF}_{3} \mathrm{SO}_{3}\right)_{2}$ electrolyte reveals a dense and dendrite-free surface morphology after $280 \mathrm{~h}$ of repeated $\mathrm{Zn}$ plating/stripping (Supplementary Fig. 25). In a $\mathrm{Zn}-\mathrm{MnO}_{2}$ full cell, neither dendritic morphology nor formation of byproducts such as $\mathrm{ZnO}$ or $\mathrm{Zn}(\mathrm{OH})_{2}$ was evidenced after rate test (Supplementary Fig. 26), favoring the cyclic stability of $\mathrm{Zn}-\mathrm{MnO}_{2}$ batteries. In contrast, in

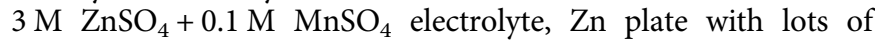
cracks formed on the zinc surface, while $\mathrm{ZnO}$ nanorods were observed in $\mathrm{KOH}$ electrolyte, which would deter the cyclability of Zn (Supplementary Figs. 25 and 27). Furthermore, the EDS analysis indicates that there is no detectable $\mathrm{Mn}$ in $\mathrm{Zn}$ anode (Supplementary Fig. 28).

\section{Discussion}

The exceptional performance of $\mathrm{Zn}-\mathrm{MnO}_{2}$ coin-type batteries has motivated us to further assess soft-packed full cells, which were facilely assembled in ambient air negating complicated 
procedures or extra protection (Supplementary Methods). Figure 7 a schematically shows the battery configuration consisting of six anode-separator-cathode stacks. A typical assembled pouch-type cell lightens a "Zn-Mn"-shape indicator containing 44 LEDs (Fig. 7b). A stable discharge capacity of $1550 \mathrm{mAh}$ can be obtained after 50 repeated cycles with an average potential of $1.35 \mathrm{~V}$ (Fig. 7c). The full cell delivers an energy density of 158.5 Wh kg-1 based on the total weight of the active materials (including both cathode and anode). This value far exceeds that of other aqueous Li-ion batteries $\left(50-90 \mathrm{Wh} \mathrm{kg}^{-1}\right)^{3}, 4,58$ and aqueous Na-ion batteries $\left(\sim 33 \mathrm{Wh} \mathrm{kg}^{-1}\right)^{8}, 16,59$. Remarkably, a total energy density of $75.2 \mathrm{Wh} \mathrm{kg}^{-1}$ is obtained according to the mass of whole battery mass, much higher than that of commercial $\mathrm{Pb}$-acid $\left(\sim 30 \mathrm{Wh} \mathrm{kg}^{-1}\right)$ and Ni-Cd technologies $\left(\sim 50 \mathrm{Wh} \mathrm{kg}^{-1}\right)^{26}$. We note that the higher price of anhydrous $\mathrm{Zn}\left(\mathrm{CF}_{3} \mathrm{SO}_{3}\right)_{2}$ salt relative to $\mathrm{ZnSO}_{4}$ and $\mathrm{KOH}$ would inevitably increase the practical cost of this aqueous $\mathrm{Zn}-\mathrm{MnO}_{2}$ battery system, even though $\mathrm{Zn}\left(\mathrm{CF}_{3} \mathrm{SO}_{3}\right)_{2}$ merely serves as charge carrier and is not consumed during battery operation. Fortunately, considering the abundant, cheap precursors (i.e., triflic acid and $\left.\mathrm{ZnCO}_{3}\right)^{60}$ and the direct usage of hydrateform salt in aqueous solution, the cost of $\mathrm{Zn}\left(\mathrm{CF}_{3} \mathrm{SO}_{3}\right)_{2}$ electrolyte could be expected to drop with the development of synthetic technique and market demand.

In conclusion, we demonstrate a high-performing rechargeable $\mathrm{Zn}-\mathrm{MnO}_{2}$ battery system based on zinc anode, $\beta-\mathrm{MnO}_{2}$ cathode, and mild acidic aqueous electrolyte. We elucidate the $\mathrm{Zn}$-insertion mechanism and structural evolution of $\mathrm{MnO}_{2}$ cathode by combining electrochemical investigations, XRD, TEM, ICP, and XANES/EXAFS analysis. A phase transition from tunneled to layered structure (Zn-buserite) occurs during the first discharge of $\mathrm{MnO}_{2}$, followed by reversible $\mathrm{Zn}^{2+}$ (de)intercalation in the $\mathrm{H}_{2} \mathrm{O}$-containing $\mathrm{Zn}$-buserite framework. Unlike previous reports, this electrode mechanism is common in polymorphs of $\alpha-\mathrm{MnO}_{2}, \gamma-\mathrm{MnO}_{2}$, and $\beta-\mathrm{MnO}_{2}$. The phase tranformation, $\mathrm{Mn}$ dissolution and electode pulverization incur capacity fade of $\mathrm{MnO}_{2}$. By formulating an aqueous $3 \mathrm{M} \mathrm{Zn}\left(\mathrm{CF}_{3} \mathrm{SO}_{3}\right)_{2}+0.1 \mathrm{M} \mathrm{Mn}$ $\left(\mathrm{CF}_{3} \mathrm{SO}_{3}\right)_{2}$ electrolyte, the $\mathrm{Mn}^{2+}$ dissolution can be effectively accommodated and the electrode integrity can be maintained because of the in-situ generated amorphous $\mathrm{MnO}_{x}$ layer. As a result, $\mathrm{Zn}-\mathrm{MnO}_{2}$ cell exhibits high capacity $\left(225 \mathrm{mAh} \mathrm{g}^{-1}\right.$ at $0.65 \mathrm{C})$, high rate capability $\left(100 \mathrm{mAh} \mathrm{g}^{-1}\right.$ at $\left.32.50 \mathrm{C}\right)$ and longterm cycling stability ( $94 \%$ capacity retention after 2000 cycles at $6.50 \mathrm{C}$ ). Furthermore, the assembled soft-packed $\mathrm{Zn}-\mathrm{MnO}_{2}$ battery can deliver a high reversible capacity of $1550 \mathrm{mAh}$ with a total energy density of $75.2 \mathrm{Wh} \mathrm{kg}^{-1}$, among the highest value achieved in aqueous battery technologies. The present $\mathrm{Zn}-\mathrm{MnO}_{2}$ system holds great promise for potential applications in largescale energy storage, in view of the remarkable electrochemical performance and other advantages such as low materials cost, easy manufacturing, high safety, and environmental friendliness.

\section{Methods}

Synthesis. $\beta-\mathrm{MnO}_{2}$ nanorods were synthesized by a hydrothermal method. In a

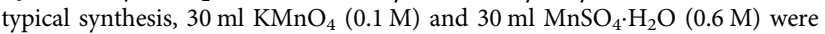
mixed under continuous stirring for $30 \mathrm{~min}$ at room temperature. The mixture was loaded into a $100 \mathrm{ml}$ Teflon-lined autoclave and maintained at $140{ }^{\circ} \mathrm{C}$ for $12 \mathrm{~h}$. The obtained product was centrifuged, washed thoroughly using water and absolute ethyl alcohol, and dried at $80^{\circ} \mathrm{C}$ for $10 \mathrm{~h}$. Bulk $\beta-\mathrm{MnO}_{2}$ powders was purchased from Alfa Aesar. $\alpha-\mathrm{MnO}_{2}$ and $\gamma-\mathrm{MnO}_{2}$ nanorods were synthesized via hydrothermal technique following previously reported procedures ${ }^{61}$.
\end{abstract}

Characterization. Powder XRD patterns were collected on a Rigaku X-ray diffractometer (MiniFlex600) with $\mathrm{Cu} \mathrm{K} \alpha$ radiation. SEM images were obtained on Field-emission JEOL JSM-7500F microscope. TEM and HRTEM images were taken on Philips Tecnai G2 F20. ABF-STEM was performed on Titan Cubed Themis G2 300 (FEI) at an acceleration voltage of $200 \mathrm{kV}$. The XAS data were collected on BL14W1 beamline of Shanghai Synchrotron Radiation Facility and analyzed with software of Ifeffit Athena ${ }^{62}$. ICP-AES measurements were conducted on a PerkinElmer Optima 8300. XPS was tested on a Perkin Elmer PHI 1600 ESCA system. Raman spectra were obtained on confocal Thermo-Fisher Scientific DXR microscope using $532 \mathrm{~nm}$ excitation. TGA was measured by a Netzsch STA 449 F3 Jupiter analyzer.

Electrochemical test. Electrochemical performance was tested using CR2032 coin-type cells. The working electrode was fabricated by blending $\mathrm{MnO}_{2}$ powder, Super P carbon and polyvinylidene fluoride in a weight ratio of 8:1:1 using $\mathrm{N}$-methyl-2-pyrrolidone as solvent. The obtained slurry was pasted onto a Ti foil and vacuum-dried at $100^{\circ} \mathrm{C}$ for $12 \mathrm{~h}$. The loading mass of active material was $\sim 2 \mathrm{mg} \mathrm{cm}^{-2}$. Filter paper and zinc foil were employed as the separator and anode, respectively. A $3 \mathrm{M} \mathrm{Zn}\left(\mathrm{CF}_{3} \mathrm{SO}_{3}\right)_{2}$ with/without $0.1 \mathrm{M} \mathrm{Mn}\left(\mathrm{CF}_{3} \mathrm{SO}_{3}\right)_{2}$ aqueous solution was used as the electrolyte. The assembled cells were galvanostatically cycled between 0.8 and $1.9 \mathrm{~V}$ using the LAND-CT2001A battery-testing instrument. Calculation of specific capacities was based on the mass of initial $\mathrm{MnO}_{2}$. CVs were measured on a Parstat 263 A electrochemical workstation (AMETEK). EIS was performed on a Parstat 2273 electrochemical workstation (AMETEK). The AC perturbation signal was $\pm 10 \mathrm{mV}$ and the frequency ranged from $100 \mathrm{kHz}$ to $100 \mathrm{mHz}$. The electrochemical behaviors of $\mathrm{Mn}^{2+}$ additive in electrolyte were characterized using three-electrode cells ( $\mathrm{Ti}$ foil as working electrode, platinum plate or Zn foil as counter electrode, and SCE as reference electrode).

Data availability. The authors declare that all the relevant data are available within the paper and its Supplementary Information file or from the corresponding author upon reasonable request.

Received: 6 January 2017 Accepted: 27 June 2017

Published online: 01 September 2017

\section{References}

1. Armand, M. \& Tarascon, J. M. Building better batteries. Nature 451, 652-657 (2008).

2. Choi, J. W. \& Aurbach, D. Promise and reality of post-lithium-ion batteries with high energy densities. Nat. Rev. Mater. 1, 16013 (2016).

3. Li, W., Dahn, J. R. \& Wainwright, D. S. Rechargeable lithium batteries with aqueous electrolytes. Science 264, 1115-1118 (1994).

4. Suo, L. et al. "Water-in-salt" electrolyte enables high-voltage aqueous lithiumion chemistries. Science 350, 938-943 (2015).

5. Lin, M. C. et al. An ultrafast rechargeable aluminium-ion battery. Nature 520, 325-328 (2015)

6. Ponrouch, A., Frontera, C., Barde, F. \& Palacin, M. R. Towards a calcium-based rechargeable battery. Nat. Mater. 15, 169 (2015).

7. Hassoun, J., Lee, K. S., Sun, Y. K. \& Scrosati, B. An advanced lithium ion battery based on high performance electrode materials. J. Am. Chem. Soc. 133, 3139-3143 (2011).

8. Kim, H. et al. Aqueous rechargeable $\mathrm{Li}$ and $\mathrm{Na}$ ion batteries. Chem. Rev. 114, 11788-11827 (2014).

9. Kundu, D. et al. A high-capacity and long-life aqueous rechargeable zinc battery using a metal oxide intercalation cathode. Nat. Energy 1, 16119 (2016).

10. Pasta, M. et al. Full open-framework batteries for stationary energy storage. Nat. Commun. 5, 3007 (2014).

11. Pasta, M., Wessells, C. D., Huggins, R. A. \& Cui, Y. A high-rate and long cycle life aqueous electrolyte battery for grid-scale energy storage. Nat. Commun. 3, 1149 (2012).

12. Lu, Y., Goodenough, J. B. \& Kim, Y. Aqueous cathode for next-generation alkali-ion batteries. J. Am. Chem. Soc. 133, 5756-5759 (2011).

13. Wang, Y. et al. Ti-substituted tunnel-type $\mathrm{Na}_{0.44} \mathrm{MnO}_{2}$ oxide as a negative electrode for aqueous sodium-ion batteries. Nat. Commun. 6, 6401 (2015).

14. Yabuuchi, N., Kubota, K., Dahbi, M. \& Komaba, S. Research development on sodium-ion batteries. Chem. Rev. 114, 11636-11682 (2014).

15. Su, D., McDonagh, A., Qiao, S. Z. \& Wang, G. High-capacity aqueous potassium-ion batteries for large-scale energy storage. Adv. Mater. 29, 1604007 (2017).

16. Shan, X. et al. Bivalence $\mathrm{Mn}_{5} \mathrm{O}_{8}$ with hydroxylated interphase for high-voltage aqueous sodium-ion storage. Nat. Commun. 7, 13370 (2016).

17. Häupler, B. et al. Aqueous zinc-organic polymer battery with a high rate performance and long lifetime. NPG Asia Mater. 8, e283 (2016).

18. Sun, $\mathrm{X}$. et al. Investigation of the mechanism of $\mathrm{Mg}$ insertion in birnessite in nonaqueous and aqueous rechargeable mg-ion batteries. Chem. Mater. 28, 534-542 (2016).

19. Bucur, C. B., Gregory, T., Oliver, A. G. \& Muldoon, J. Confession of a magnesium battery. J. Phys. Chem. Lett. 6, 3578-3591 (2015). 
20. González, M. A. et al. Layered double hydroxides as a suitable substrate to improve the efficiency of $\mathrm{Zn}$ anode in neutral $\mathrm{pH} \mathrm{Zn}$-ion batteries. Electrochem. Commun. 68, 1-4 (2016).

21. Trócoli, R. \& La Mantia, F. An aqueous zinc-ion battery based on copper hexacyanoferrate. ChemSusChem. 8, 481-485 (2015).

22. Tahil, W. The zinc air battery and the zinc economy: A virutuous circle. Available at: www.meridian-int-res.com/Projects/The_Zinc_Air_Solution.pdf (Meridian International Research, 2007).

23. Chamoun, M. et al. Hyper-dendritic nanoporous zinc foam anodes. NPG Asia Mater 7, e178 (2015).

24. Zhang, N. et al. Cation-deficient spinel $\mathrm{ZnMn}_{2} \mathrm{O}_{4}$ cathode in $\mathrm{Zn}\left(\mathrm{CF}_{3} \mathrm{SO}_{3}\right)_{2}$ electrolyte for rechargeable aqueous $\mathrm{Zn}$-ion battery. J. Am. Chem. Soc. 138, 12894-12901 (2016).

25. Cheng, Y. et al. Highly reversible zinc-ion intercalation into chevrel phase $\mathrm{Mo}_{6} \mathrm{~S}_{8}$ nanocubes and applications for advanced zinc-ion batteries. ACS Appl. Mater. Interfaces 8, 13673-13677 (2016).

26. Linden, D. \& Reddy, T. Handbook of Batteries 3rd edn (McGraw-Hill, 2002).

27. Winter, M. \& Brodd, R. J. What are batteries, fuel cells, and supercapacitors? Chem. Rev. 104, 4245-4270 (2004).

28. Cheng, F. Y., Chen, J., Gou, X. L. \& Shen, P. W. High-power alkaline $\mathrm{Zn}-\mathrm{MnO}_{2}$ batteries using $\gamma-\mathrm{MnO}_{2}$ nanowires/nanotubes and electrolytic zinc powder. Adv. Mater. 17, 2753-2756 (2005).

29. Kannan, A. M. et al. Characterization of the bismuth-modified manganese dioxide cathodes in rechargeable alkaline cells. J. Electrochem. Soc. 149, A483 (2002).

30. McLarnon, F. R. \& Cairns, E. J. The secondary alkaline zinc electrode. J. Electrochem. Soc. 138, 645-656 (1991).

31. Shen, Y. \& Kordesch, K. The mechanism of capacity fade of rechargeable alkaline manganese dioxide zinc cells. J. Power Sources 87, 162-166 (2000).

32. Gibson, A. J. et al. Dynamic electrodeposition of manganese dioxide: Temporal variation in the electrodeposition mechanism. J. Electrochem. Soc. 163, H305-H312 (2016).

33. Xu, C., Li, B., Du, H. \& Kang, F. Energetic zinc ion chemistry: The rechargeable zinc ion battery. Angew. Chem. Int. Ed. 51, 933-935 (2012).

34. Alfaruqi, M. H. et al. Electrochemically induced structural transformation in a $\gamma-\mathrm{MnO}_{2}$ cathode of a high capacity zinc-ion battery system. Chem. Mater. 27, 3609-3620 (2015).

35. Pan, H. et al. Reversible aqueous zinc/manganese oxide energy storage from conversion reactions. Nat. Energy 1, 16039 (2016).

36. Lee, B. et al. Elucidating the intercalation mechanism of zinc ions into small alpha- $\mathrm{MnO}_{2}$ for rechargeable zinc batteries. Chem. Commun. 51, 9265-9268 (2015).

37. Lee, J. et al. Todorokite-type $\mathrm{MnO}_{2}$ as a zinc-ion intercalating material. Electrochim. Acta 112, 138-143 (2013).

38. Lee, B. et al. Electrochemically-induced reversible transition from the tunneled to layered polymorphs of manganese dioxide. Sci. Rep. 4, 6066 (2014).

39. Yuan, Y. et al. The influence of large cations on the electrochemical properties of tunnel-structured metal oxides. Nat. Commun. 7, 13374 (2016).

40. Jiao, F. \& Bruce, P. G. Mesoporous crystalline $\beta-\mathrm{MnO}_{2}-\mathrm{a}$ reversible positive electrode for rechargeable lithium batteries. Adv. Mater. 19, 657-660 (2007).

41. Tompsett, D. A., Parker, S. C. \& Islam, M. S. Rutile ( $\beta-) \mathrm{MnO}_{2}$ surfaces and vacancy formation for high electrochemical and catalytic performance. J. Am. Chem. Soc. 136, 1418-1426 (2014).

42. Wei, C. et al. Preparation and characterization of manganese dioxides with nano-sized tunnel structures for zinc ion storage. J. Phys. Chem. Solids 73, 1487-1491 (2012)

43. Yamada, A. et al. Room-temperature miscibility gap in $\mathrm{Li}_{\mathrm{x}} \mathrm{FePO}_{4}$. Nat. Mater. $\mathbf{5}$, 357-360 (2006)

44. Luo, J. et al. Double-aging method for preparation of stabilized Na-buserite and transformations to todorokites incorporated with various metals. Inorg. Chem. 38, 6106-6113 (1999).

45. Post, J. E. Manganese oxide minerals: Crystal structures and economic and environmental significance. Proc. Natl Acad. Sci. 96, 3447-3454 (1999).

46. Golden, D. C., Chen, C. C. \& Dixon, J. B. Transformation of birnessite to buserite, todorokite, and manganite under mild hydrothermal treatment. Clays Clay Miner 35, 271-280 (1987).

47. Tepavcevic, S. et al. Nanostructured bilayered vanadium oxide electrodes for rechargeable sodium-ion batteries. ACS Nano 6, 530-538 (2012).

48. $\mathrm{Hu}, \mathrm{Y}$. Y. et al. Origin of additional capacities in metal oxide lithium-ion battery electrodes. Nat. Mater. 12, 1130-1136 (2013).

49. Lu, J. et al. Effectively suppressing dissolution of manganese from spinel lithium manganate via a nanoscale surface-doping approach. Nat. Commun. 5, 5693 (2014).
50. Kim, C. et al. Direct observation of reversible magnesium ion intercalation into a spinel oxide host. Adv. Mater. 27, 3377-3384 (2015).

51. Zhang, R. et al. $\alpha-\mathrm{MnO}_{2}$ as a cathode material for rechargeable $\mathrm{Mg}$ batteries. Electrochem. Commun. 23, 110-113 (2012).

52. Li, C. et al. Phase and composition controllable synthesis of cobalt manganese spinel nanoparticles towards efficient oxygen electrocatalysis. Nat. Commun. 6 , 7345 (2015).

53. Thackeray, M. M. et al. Structural fatigue in spinel electrodes in high voltage (4 V) $\mathrm{Li} / \mathrm{Li}_{\mathrm{x}} \mathrm{Mn}_{2} \mathrm{O}_{4}$ cells. Electrochem. Solid-State Lett. 1, 7-9 (1998).

54. Nam, K. W., Kim, M. G. \& Kim, K. B. In situ Mn K-edge X-ray absorption spectroscopy studies of electrodeposited manganese oxide films for electrochemical capacitors. J. Phys. Chem. C 111, 749-758 (2007).

55. Alfaruqi, $\mathrm{M}$. H. et al. A layered $\delta-\mathrm{MnO}_{2}$ nanoflake cathode with high zincstorage capacities for eco-friendly battery applications. Electrochem. Commun. 60, 121-125 (2015).

56. Ramanujapuram, A. et al. Degradation and stabilization of lithium cobalt oxide in aqueous electrolytes. Energy Environ. Sci. 9, 1841-1848 (2016).

57. Zhang, L., Chen, L., Zhou, X. \& Liu, Z. Towards high-voltage aqueous metalion batteries beyond $1.5 \mathrm{~V}$ : The zinc/zinc hexacyanoferrate system. Adv. Energy Mater. 5, 1400930 (2015)

58. Luo, J. Y., Cui, W. J., He, P. \& Xia, Y. Y. Raising the cycling stability of aqueous lithium-ion batteries by eliminating oxygen in the electrolyte. Nat. Chem. 2, 760-765 (2010)

59. Li, Z. et al. Towards high power high energy aqueous sodium-ion batteries: The $\mathrm{NaTi}_{2}\left(\mathrm{PO}_{4}\right)_{3} / \mathrm{Na}_{0.44} \mathrm{MnO}_{2}$ system. Adv. Energy Mater 3, 290-294 (2013).

60. Chandak, H., Sarode, P. \& Bahekar, S. Zn(OTf $)_{2}$-mediated expeditious and solvent-free synthesis of propargylamines via $\mathrm{C}-\mathrm{H}$ activation of phenylacetylene. Synlett 27, 2209-2212 (2016).

61. Cheng, F. et al. Facile controlled synthesis of $\mathrm{MnO}_{2}$ nanostructures of novel shapes and their application in batteries. Inorg. Chem. 45, 2038-2044 (2006).

62. Yu, H. et al. The XAFS beamline of SSRF. Nucl. Sci. Tech. 26, 050102 (2015)

\section{Acknowledgements}

This work was supported by MOST (2016YFA0202500 and 2017YFA0206702), NSFC (21231005, 21473235, and 11227902) and MOE (B12015, ACET-13-0296, and IRT13R30).

\section{Author contributions}

N.Z., J.L., and L.W. conducted the synthesis. N.Z. carried out the characterization and the electrochemical measurements. N.Z., F.C., and J.C. co-wrote the manuscript. N.Z., F.C., and X.L. analyzed the results of synchrotron X-ray absorption spectroscopy. All authors discussed the data and commented on the manuscript. F.C. and J.C. directed the research.

\section{Additional information}

Supplementary Information accompanies this paper at doi:10.1038/s41467-017-00467-x.

Competing interests: The authors declare no competing financial interests.

Reprints and permission information is available online at http://npg.nature.com/ reprintsandpermissions/

Publisher's note: Springer Nature remains neutral with regard to jurisdictional claims in published maps and institutional affiliations.

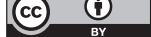

Open Access This article is licensed under a Creative Commons Attribution 4.0 International License, which permits use, sharing, adaptation, distribution and reproduction in any medium or format, as long as you give appropriate credit to the original author(s) and the source, provide a link to the Creative Commons license, and indicate if changes were made. The images or other third party material in this article are included in the article's Creative Commons license, unless indicated otherwise in a credit line to the material. If material is not included in the article's Creative Commons license and your intended use is not permitted by statutory regulation or exceeds the permitted use, you will need to obtain permission directly from the copyright holder. To view a copy of this license, visit http://creativecommons.org/ licenses/by/4.0/.

(C) The Author(s) 2017 